\title{
KAJIAN PERMASALAHAN, KEBUTUHAN DAN POTENSI PENGEMBANGAN PETERNAKAN PADA KAWASAN AGRO-EKOLOGI TAMBRAUW, PAPUA BARAT
}

\section{CONSTRAINTS, NEEDS AND DEVELOPMENT POTENCY OF LIVESTOCK SECTOR ON AGRO-ECOLOGICAL REGION OF TAMBRAUW, WEST PAPUA}

\author{
Meky Sagrim $^{1)}$ dan Deny Anjelus Iyai ${ }^{2)}$ \\ ${ }^{1)}$ Fakultas Pertanian, Universitas Papua \\ ${ }^{2)}$ Fakultas Peternakan. Universitas Papua \\ email: da.iyai@yahoo.com
}

\begin{abstract}
ABSTRAK
Produksi pertanian yang dihasilkan belum dihasilkan dari produksi potensial. Produksi yang dihasilkan masih produksi minimal yang sebenarnya dapat ditingkatkan secara maksimal. Keterbatasan dijumpai pada aspek hulu dan hilir sistim peternakan. Tujuan penelitian ini adalah untuk mengetahui permasalahan, kebutuhan dan potensi pengembangan peternakan di kabupaten Tambrauw. Penelitian deskriptif dengan teknik wawancara dan observasi di Distrik Sausapor dilakukan terhadap delapan informan kunci. Pertanyaan difokuskan pada permasalahan, kebutuhan dan potensi sumberdaya alam yang dimiliki oleh peternak. Data dianalisis secara deskriptif naratif dan disajikan dalam bentuk cause-effect diagram, tabulasi dan gambar. Hasil penelitian menunjukkan bahwa terdapat empat persoalan dasar yaitu rendahnya pelatihan, tidak adanya pos pelayanan pertanian terpadu, sumberdaya manusia pada instansi teknis yang kurang, dan minimnya data potensi sumberdaya alam. Pengembangan masyarakat pelaku usahatani peternakan menjadi sentral isu dalam hal pemberdayaan/pembinaan. Sarana dan prasarana menjadi strategis untuk dikembangkan seperti kantor pos pelayanan pertanian terpadu (P3T). Sumberdaya petugas penyuluh dan tenaga teknis seperti inseminator, dokter hewan dan tenaga paramedis diprogramkan oleh Dinas Peternakan. Pembibitan Hijauan Pakan Ternak perlu dikembangkan bersamaan dengan itu klinik pembibitan ternak menjadi rekomendasi jangka menengah.
\end{abstract}

Kata kunci: kebun bibit; mini ranch; multi aksesibilitas; pelayan pertanian terpadu

\section{ABSTRACT}

Agricultural yields do not produce from farming yields potential yet. It is lower production, which can optimally be increased. Limiting factors are hampering off-farm and on-farm livestock farming systems. The objective of doing this research is to keen on constraints, needs and developing potency in Tambrauw regency. The finding of this research was that the regency has potency in developing livestock farming. This can be done by adapting the development of livestock farming based on the land characteristic. Community development becomes central issues in the case of community empowering. Infrastructures become strategic in further development, such as integrated agricultural service 
office. The local government shall prepare human resources, such as extension officers, inseminators, veterinarians, and paramedics. The community will recommend forage seeds need to be developed and veterinary clinic in the middle term period.

Key words: integrated agricultural services; mini ranch; multi-accessibility; seedling farm

\section{PENDAHULUAN}

Kabupaten Tambrauw adalah salah satu kabupaten di Provinsi Papua Barat hasil pemekaran dari Kabupaten Sorong yang terletak di antara $131^{\circ} 59^{\prime} 42,58^{\prime \prime}-133^{\circ}$ $28^{\prime} 02,35^{\prime \prime}$ BT dan 00²0'27,74”01²2’30,36” LS (BPS, Tambrauw, 2017). Situasi ideal pengembangan masyarakat dengan usahataninya yang kompleks yang ingin dicapai adalah peningkatan kapasitas usahatani masyarakat Tambrauw yang berdampak pada peningkatan pendapatan dan kesejahteraan/kapita rumah tangga tani/ternak di Kabupaten Tambrauw secara berkelanjutan dengan pemanfaatan peruntukan lahan yang tersedia yang lestari dengan lingkungan (Fatem dan Asem, 2015). Diperkirakan total luas lahan yang dialokasikan untuk pengembangan hanya sebesar $18 \%$ dari total luas Tambrauw 5.188,64 $\mathrm{km}^{2}$ (tidak termasuk distrik Kebar, Senopi, Mubrani, Amberbaken) dan sebesar $10.571,55 \mathrm{~km}^{2}$, jika diikuti oleh keempat distrik tadi.

Di Kabupaten Tambrauw terdapat komoditi ternak yang dapat dikategorikan menjadi komoditi yang dapat dipelihara dalam jangka waktu singkat dan menghasilkan pendapatan (high return) bagi peternak dan dipelihara dalam waktu yang lama dan komoditi ternak yang lambat memberikan pendapatan bagi peternak (slow return).

Komoditi ternak yang dipelihara meliputi ternak ayam, babi, dan kambing serta ternak sapi (Priyanto dan Irawan, 2008). Ternakternak tersebut adalah ternak konvensional introduksi yang belum menjadi komoditi andalan karena pemeliharaannya dilakukan secara ekstensif. Sistem usahatani ternak yang telah eksis dan dapat dikembangkan di masyarakat beragam. Namun dalam pengembangannya sistem usahatani ternak ini relatif belum dipetakan dan diketahui dengan baik. 
Seperti diketahui bahwa di kawasan pesisir saja, dikarenakan karakteristik edapik, sumberdaya alam yang tersedia dan budaya masyarakat, pola usahatani ternak dapat bervariasi seperti yang ditemukan pada distrik Sausapor yang relatif mirip dengan distrik Kwoor, Amberbaken dan Mubrani namun tidak mirip seperti yang ada di distrik Abun. Masyarakat Tambrauw adalah salah satu penyuplai kebutuhan komoditi pertanian di kabupaten dan kota terdekat seperti Sorong dan Manokwari. Dengan hanya mengandalkan pengetahuan seadanya, komoditi pertanian masyarakat dapat diproduksi, tetapi kurang optimal. Tentunya keterbatasan (constraints) masih dijumpai pada aspek hulu dan hilir sistim peternakan serta aspek sarana dan prasarananya (Mustofa et al., 2015) yang sangat urgen untuk dikaji solusinya. Mengetahui dan memahami dinamika sistim/corak usahatani yang eksis di masyarakat yang meliputi input yang digunakan, bagaimana input diaplikasikan di dalam proses usahatani dan output yang dihasilkan, maka berbagai keputusan bijak dalam rangka perbaikan dan pengembangan sistem usahatani dapat dikembangkan. Hal prinsip yang perlu mendapat prioritas adalah sumberdaya manusia peternak. Sumberdaya manusia peternak di kabupaten Tambrauw masih memiliki keterisolasian dalam aspek faktor penunjang keberhasilan usahatani ternak.

Keterisolasian sarana transportasi, informasi hulu peternakan tentang pengetahuan produksi dan makanan ternak, kesehatan ternak, modal usaha (Elly et. al., 2008) dan bentuk pembinaan. Dengan demikian sangat mendesak untuk diketahui hal-hal mulai dari aspek, pra-produksi, produksi, pascaproduksi dan tataniaga/agribisnisnya, sehingga dapat diambil benang merahnya sebagai dasar berpijak dalam mendesain rencana induk pembangunan pertanian di Tambrauw. Tujuan penelitian ini adalah untuk mengetahui permasalahan bidang peternakan, kebutuhan dan potensi pengembangan peternakan di Kabupaten Tambrauw.

\section{METODE PENELITIAN}

Kajian lapangan dilaksanakan selama kurang lebih satu minggu dari 
tanggal enam sampai dengan dua belas November pada kampung Werur, Wertam dan Werbes, Distrik Sausapor. Dilanjutkan kunjungan ke kampung Hopmare dan Kwoor, Distrik Kwoor. Kunjungan tidak dapat dilakukan di Distrik Yembun, Syujak dan Fef karena alasan aksesibilitas wilayah.

Metode penelitian deskriptif dengan teknik wawancara dan observasi dilakukan di Tambrauw. Sebanyak tiga kampung di Distrik Sausapor dilakukan sampling sebagai studi kasus (Yin, 2000). Pencatatan posisi lintang dilakukan dengan menggunakan GPS.

Responden kunci yaitu aparat kampung menjadi sentral informan untuk kondisi sosial ekonomi masyarakat. Observasi cepat dilakukan untuk mendapatkan potret kondisi eksisting biofisik sistem kebun. Sumber data diperoleh dari hasil interview dan studi pustaka (Moleong, 1991). Respon yang telah berpartisipasi adalah sebanyak 8 orang responden kunci dengan sebaran umur 30-74 tahun yang bekerja sebagai aparat kampung, tokoh pemuda, pelaku bisnis pertanian dan tokoh masyarakat. Selain etnis Karon yang melakukan usahatani beternak, etnis non-Papua seperti Jawa, Bugis dan Flores juga terdapat di Werbes. Parameter yang digunakan adalah informasi tentang permasalahan, kebutuhan, peluang pengembangan, dan pengembangan sarana produksi. Permasalahan peternakan secara khusus meliputi aspek produksi ternak, hijauan pakan ternak, manajemen dan saranaprasarana penunjang pembangunan peternakan. Kebutuhan dan peluang pengembangan meliputi potensi tenaga kerja, pembinaan dan pendampingan oleh petugas teknis pemerintah. Sarana dan prasarana teknis meliputi pembibitan, potensi ranch, infrastruktur dan kondisi lingkungan hidup.

Analisis data dilakukan secara deskriptif-naratif (Santoso, 2012; Asra and Sutomo, 2016; Field, et al., 2012). Hasil analisis data narasi disajikan dalam bentuk diagram analisis cause-effect (Manly and Alberto, 2015). Hasil analisis data disajikan dalam bentuk gambar dan diagram yang dibuat menggunakan Microsoft Office Visio. 


\section{HASIL DAN PEMBAHASAN}

\section{Permasalahan}

Dari hasil observasi lapang, penilaian (persepsi) masyarakat peternak tentang usahatani ternak yang dijalankan berada pada jawaban "ketidakpuasan" kondisi peternakan yang telah eksis. Beberapa hal yang menjadi permasalahan umum dan khusus di kabupaten Tambrauw adalah rendahnya multi aksesibilitas teknis peternakan. Analisis permasalahan peternakan di Kabupaten Tambrauw dapat dijabarkan dalam Gambar 1. Penyebab (Causes) adalah faktor/halhal yang menstimulasi dan memiliki hubungan (interaksi) antara satu aspek dengan aspek lainnya dan effect adalah dampak dari hasil hubungan satu aspek dengan aspek lain yang tidak seimbang atau balans dan cenderung menghasilkan permasalahan atau penyebab itu sendiri. Di kabupaten Tambrauw persoalan krusial yang muncul adalah rendahnya multi aksesibilitas teknis. Oleh sebab itu, dibutuhkan energi yang besar dari segi kebijakan, regulasi, finansial, asistensi dan monitoring dan evaluasi (monev) sehingga program-program peningkatan dan percepatan pembangunan di Tambrauw dapat lebih ditingkatkan.

Prasarana dan sarana transportasi masih menjadi persoalan krusial dalam jangka pendek. Hal ini juga disampaikan oleh Kutsiah (2017) di Madura. Transportasi darat belum memadai disebabkan oleh prasarana transportasi yang belum dikembangkan. Penyebab utama adalah minimnya alokasi pendanaan insfrastruktur daerah. Karenanya, saat ini pemerintah pusat mencanangkan infrastruktur sebagai modal utama penggerak pembangunan daerah dan bangsa. Dukungan pemerintah berkorelasi positif dalam upaya penggiatan pengembangan peternakan di daerah seperti disampaikan oleh Mustofa et al. (2015) di Lamongan. Dari aspek/bidang transportasi laut sudah berjalan dengan lancar. Pengetahuan teknis agribisnis menyangkut produksi, manajemen dan pasca panen menjadi sentral isu. Pengetahuan peternak menentukan penguasaan teknologi (Yoyo et al., 2013). Hal ini dirasakan penting karena Kabupaten ini memiliki potensi sumberdaya pertanian, peternakan dan perkebunan yang potensial. Pengetahuan agribisnis 
petani dipengaruhi oleh kemampuan petani untuk menyerap informasi. Di Lamongan pengetahuan peternakan berkorelasi negatif terhadap kemauan membuka usahatani ternak sapi. Kemampuan penyerapan informasi dipengaruhi oleh tingkat pendidikan baik formal dan non formal dan serta kehadiran pos pelayanan pertanian terpadu (P3T). Pelayanan pertanian dapat berupa penyuluhan dan pertanian. Penyuluhan berkorelasi positif dengan pembukaan dan produksitiftas usaha tani ternak (Mustofa et al., 2015; Jafri et al., 2015; Elly et al., 2008). Penyelenggaraan pendidikan formal dan non formal serta pos pelayanan pertanian terpadu dapat berjalan bila didukung oleh kebijakan penganggaran yang rutin dari pemerintah.

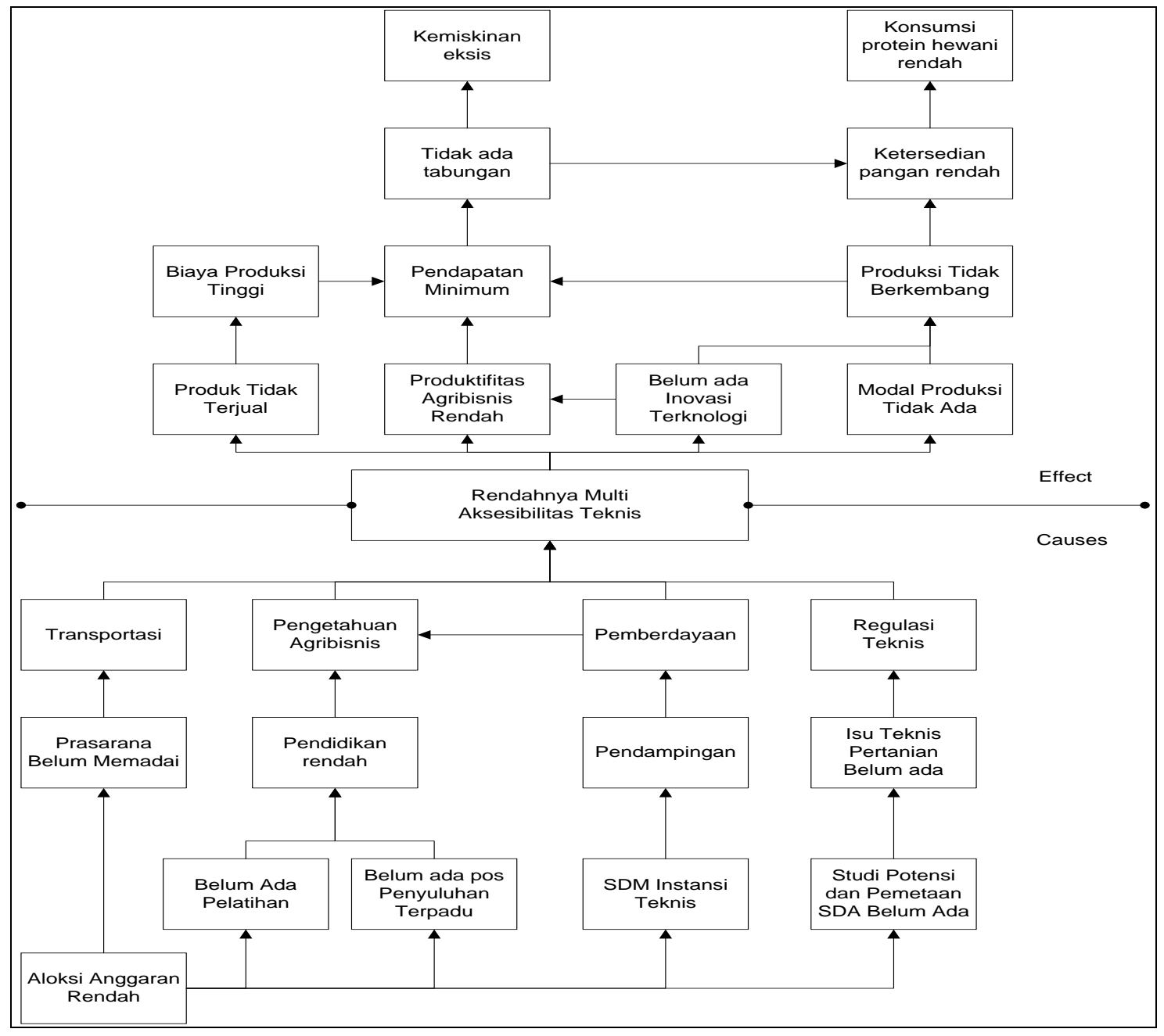

Gambar 1. Diagram Pohon Masalah Pembangunan Pertanian di Kabupaten Tambrauw 
Pendanaan

program

pemberdayaan masyarakat kampung (pemerintah kampung, perempuan dan keluarga) selama ini baru sebesar Rp. 359.725.000,-, dimana masih sangat minim alokasi pendanaan, misalnya modal usaha seperti yang disampaikan oleh Mukson et al. (2015) di Jawa Tengah. Program pemberdayaan dipengaruhi oleh pendampingan secara reguler dimana frekuensi dan aktifitasnya ditentukan juga oleh sumberdaya manusia instansi teknis yang berkompeten. Dari hasil pengamatan penyuluh pertanian di Tambrauw belum menunjukkan kapasitas sebagai penyuluh yang efektif karena belum ditunjang dengan kebijakan penganggaran baik dalam fasilitas maupun tunjangan aktifitasnya di lapang.

Regulasi teknis dari pihak eksekutif yang berpihak kepada komunitas masyarakat petani perlu diinisiasi dengan baik. Kemampuan membuat kebijakan publik berkaitan dengan pembangunan pertanian perlu dibuat berdasarkan isu-isu teknis pembangunan pertanian yang dapat diangkat/disuarakan melalui kajian mendalam sehingga menjadi kebijakan publik dari pemerintah.
Dengan demikian kebijakan yang dibuat pemerintah kabupaten Tambrauw adalah kebijakan pembangunan berbasis penelitian dan lebih bersifat bottom up daripada top down-based development.

\section{Kebutuhan}

Analisis kebutuhan pembangunan peternakan di kabupaten Tambrauw didasarkan pada hasil observasi lapang kondisi biofisik usahatani, aspirasi peternak dan petani, konsultasi teknis dengan instansi teknis dan database yang tersedia. Analisis kebutuhan disajikan pada Tabel 2.

Rencana pembangunan dan peruntukan kawasan dan sarana prasarana di kabupaten Tambrauw mengikuti arahan RTRW kabupaten Tambrauw tahun 2011-2030. Dalam arahan RTRW kawasan budidaya pertanian dan perkebunan dapat dilakukan pada sejumlah distrik sesuai dengan potensi dan permasalahan teknis biofisik lahan (Winarso, et al., 2005) dan semangat kabupaten Tambrauw sebagai kabupaten Konservasi. Secara skematik usulan draft posisi rencana pengembangan pembangunan sektor peternakan di Kabupaten Tambrauw disajikan pada Gambar 2. 
Tabel 2. Analisis kebutuhan pembangunan peternakan di kabupaten Tambrauw.

\begin{tabular}{|c|c|c|c|c|}
\hline No. & Jenis kebutuhan & Volume & Instansi & Lokasi \\
\hline 1. & $\begin{array}{l}\text { Pos Pelayanan } \\
\text { Pertanian Terpadu }\end{array}$ & 4 Rumah & $\begin{array}{l}\text { Dinas } \\
\text { Pertanian+Peternak } \\
\text { an+ } \\
\text { Perikanan }\end{array}$ & $\begin{array}{l}\text { Kwoor+Amberbaken+Fef }+ \\
\text { Senopi }\end{array}$ \\
\hline 2. & $\begin{array}{l}\text { Perbaikan bibit } \\
\text { Tanaman HPT } \\
\text { Pembentukan }\end{array}$ & 2 hektar & Dinas Peternakan & Sausapor+Kebar+Yembun \\
\hline 3. & $\begin{array}{l}\text { kelompok } \\
\text { Peternakan/Pertanian } \\
\text { Permanen }\end{array}$ & 4 kelompok & Distrik & $\begin{array}{l}\text { Kwoor+Amberbaken+Fef }+ \\
\text { Senopi }\end{array}$ \\
\hline 4. & $\begin{array}{l}\text { Klinik Pembibitan } \\
\text { Ternak }\end{array}$ & 1 buah & Dinas Peternakan & Kebar/Senopi \\
\hline 5. & $\begin{array}{l}\text { Menghubungkan } \\
\text { Bank dengan } \\
\text { Kelompok Peternak }\end{array}$ & Rutin & $\begin{array}{l}\text { Kerjasama Dinas } \\
\text { Peternakan+Bank } \\
\text { Papua }\end{array}$ & $\begin{array}{l}\text { Sausapor+Sentra peternakan } \\
\text { (Senopi+Kebar) }\end{array}$ \\
\hline 6. & $\begin{array}{l}\text { Pengangkatan SDM } \\
\text { penyuluh peternakan }\end{array}$ & $\begin{array}{l}2 \text { orang tiap } \\
\text { Distrik }\end{array}$ & Dinas Peternakan & $\begin{array}{l}\text { Kwoor+Amberbaken+Fef+ } \\
\text { Senopi }\end{array}$ \\
\hline 7. & Inseminator & $\begin{array}{l}1 \text { orang tiap } \\
\text { Klinik Hewan }\end{array}$ & Dinas Peternakan & Sausapor+Kebar \\
\hline 8. & $\begin{array}{l}\text { Tenaga Kesehatan } \\
\text { Hewan }\end{array}$ & $\begin{array}{l}2 \text { orang Dokter } \\
\text { Hewan }+4 \\
\text { Paramedis }\end{array}$ & Dinas Peternakan & $\begin{array}{l}1 \text { orang dokter hewan di } \\
\text { Sausapor+ } 2 \text { tenaga } \\
\text { paramedis } \\
1 \text { orang dokter hewan di } \\
\text { Senopi/Kebar+2 orang } \\
\text { paramedis }\end{array}$ \\
\hline
\end{tabular}

Sumber: Analisis data

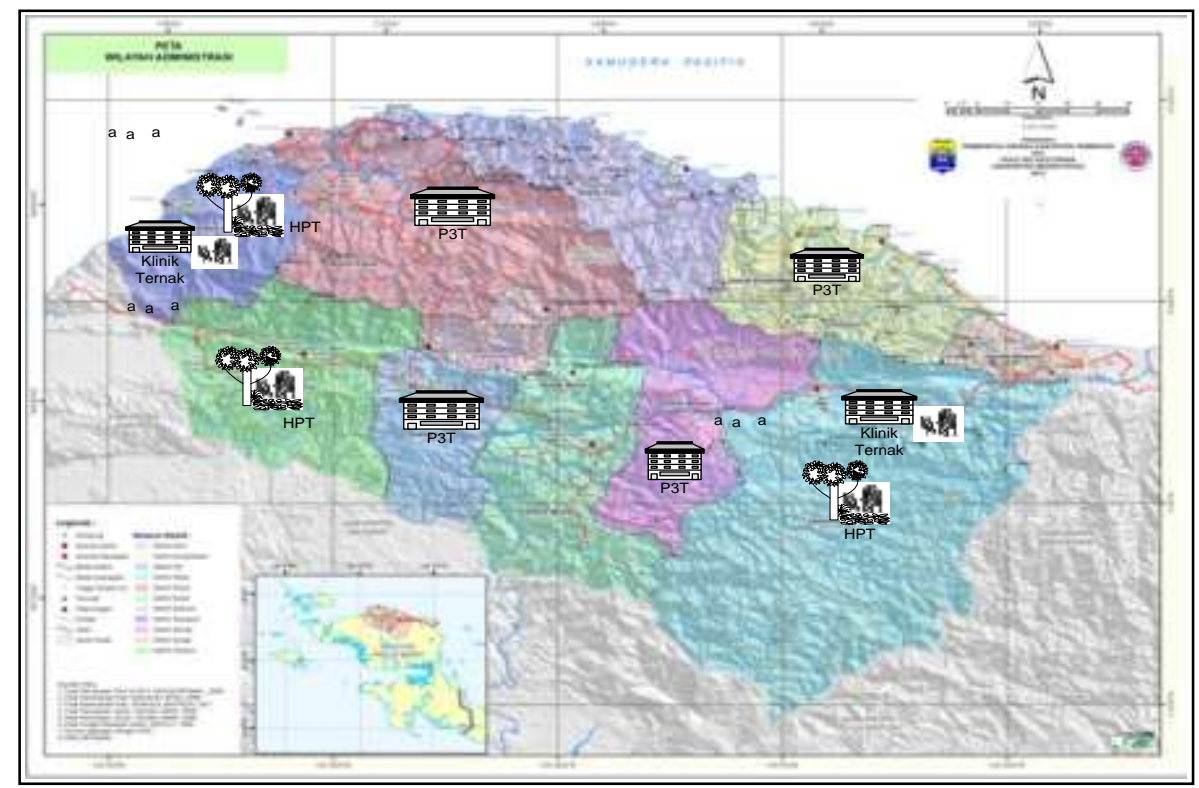

Gambar 2.Kebutuhan Sarana dan Prasarana Pembangunan Peternakan di Kabupaten Tambrauw. Keterangan:P3T = Pos Pelayanan Pertanian Terpadu (Kwoor, Amberbaken, Fef, Senopi).HPT: Pusat Pembibitan Hijauan Pakan Ternak (Sausapor, Yembun, Kebar). Klinik Ternak (Sausapor, Kebar). 


\section{Peluang Pengembangan}

Karena peternak adalah pelaku bisnis dan peternak seharusnya ditempatkan sebagai pelaku (subyek) dalam pembangunan bukan sebagai obyek (Yunasaf, 2008 disitasi Yoyo, 2013), maka sumberdaya manusia peternak perlu dikembangkan secara berkelanjutan untuk mensuplai tenaga kerja bidang peternakan. Pembinaan dan pendampingan yang serius secara kontinyu pada periode waktu yang cukup dapat memampukan peternak untuk siap mengelola aset sumberdaya peternakannya secara efektif dan efisien. Hal yang sama disarankan oleh Mustofah, et al. (2015) di Lamongan. Dari sisi kelembagaan, karena tidak terdapat kelembagaan yang sedang eksis di masyarakat, maka aspek kelembagaan yang adaptif dan cocok dengan budaya dan sosial ekonomi masyarakat setempat perlu untuk dikembangkan. Hal ini disimpulkan oleh Rahmanto (2004). Lembaga sosial ekonomi yang dapat dikembangkan untuk memfasilitasi peternak adalah dapat berupa koperasi. Koperasi di distrik Fef berjumlah 4 unit. Sementara Distrik Syujak dan Yembun belum didirikan koperasi. Di Abun sebanyak 2 unit koperasi telah didirikan, sedangkan Distrik Miyah terdapat satu unit koperasi dan Kwoor sebanyak 2 unit.

Kelembagaan dari sisi pembinaan dan pendampingan oleh instansi teknis menjadi urgen untuk dilaksanakan. Pos Pelayanan Pertanian Terpadu (P3T) menjadi penting untuk ditempatkan pada beberapa kawasan strategis pengembangan pertanian terpadu. Misalnya di wilayah pesisir, distrik Kwoor bisa dimungkinkan untuk ditempatkan pos P3T karena fasilitas pasar telah dibangun disana. Selain itu kawasan agro-ekologis pesisir lain yang dapat dijadikan pos P3T (unit pelayanan teknis, UPT) adalah di distrik Amberbaken. Pada kawasan agro-ekologis dataran tinggi dapat diusulkan 2 pos P3T yaitu di Distrik Fef dan Senopi. Dengan demikian terdapat 4 rumah pos perwakilan Pelayanan Pertanian Terpadu di kabupaten Tambrauw.

Sistem peternakan sapi skala ranch kecil, sistim ternak kambing berbasis agroekologi pesisir, sistim peternakan kambing berbasis kelapa, sistim peternakan sapi berbasis tanaman kelapa, dan sistim peternakan berbasis sayur mayur 
adalah model-model sistim peternakan yang dimungkinkan dapat diintegrasikan dengan komoditi pertanian dan perkebunan termasuk residu yang dihasilkan. Pola yang terakhir adalah model pengembangan sistim peternakan berbasis sayur mayur yang memiliki prospek pada petani di daerah Tambrauw seperti di daerah Fef, Senopi dan Yembun. Namun memang perlu diketahui secara detail potensi dan produksi limbah pertanian pada pusat-pusat tanaman pertanian di Tambrauw.

\section{Pengembangan Sarana Produksi}

Pengembangan sarana produksi peternakan yang dimaksudkan pada bagian ini meliputi kebun bibit hijauan pakan ternak, mini ranch peternakan, pengembangan infrastruktur dan lingkungan hidup. Kebun bibit hijauan pakan ternak (HPT) di kabupaten Tambrauw perlu untuk dikembangkan untuk menjamin ketersediaan bibit (seeds). Seperti yang sudah dilakukan di Sumatera Selatan (Bamualim dan Subowo, 2005). Hal ini secara nasional juga disampaikan oleh Mayulu, et al. (2010) dan Mukson, et al. (2015). Diperkirakan bahwa beberapa daerah strategis pengembangan kawasan sentra produksi ternak sapi skala nasional di Distrik Kebar dan juga Senopi menjadi pertimbangan tersendiri dalam mendirikan lahan pembibitan HPT. Membiasakan peternak lokal Papua memelihara ternak secara intensif membutuhkan proses dan waktu serta action yang terstruktur dan terarah. Mini ranch adalah luasan lahan yang dapat dikembangkan untuk menjadi model demonstrasi plot untuk menguji pola pemeliharaan ternak sapi dan atau kambing secara kelompok pada skala kecil secara intensif.

Hasil studi menunjukkan kapasitas tampung lahan padang penggembalaan di Tambrauw rendah yaitu hanya 2 ekor/hektar. Namun peningkatkan kapasitas tampung di Tambrauw dapat ditingkatkan menjadi 29 ekor/hektar dengan penyediaan pakan ternak melalui budidaya HPT di Tambrauw. Hal yang sama juga disampaikan oleh Mirah, et al. (2015) di Sulawesi Utara. Luasan lahan yang dibutuhkan dapat menampung kurang lebih $>10$ ekor betina dengan 1 ekor pejantan. Jika 1 ekor membutuhkan 0,25 Ha, maka dibutuhkan 2,5 $\mathrm{Ha}$ lahan/kelompok. Kelompok yang 
dapat dibentuk disarankan mengikuti sifat penggabungan marga/klans. Misalnya dipesisir marga "Yesa"; dataran rendah marga "Yesnat" dan dataran tinggi marga "Bame". Pola pemeliharaan intensif di dalam rumah ternak (kandang) belum direkomendasikan sepanjang ada perlakuan dalam bentuk pendampingan dan pemberdayaan yang terarah dan terukur dari instansi teknis terkait. Namun dapat dijadikan program jangka menengah sampai jangka panjang untuk intensifikasi tani-ternak di Tambrauw.

Jalan raya, jembatan, pelabuhan laut skala mini merupakan infrastruktur yang dibutuhkan saat ini. Sapras seperti ini yang disampaikan oleh Talib, et al. (2007) dan Mukson, et al. (2015) sangat strategis untuk disiapkan saat ini. Penempatan/Letak prasarana ini menjadi keputusan instansi teknis terkait dimana dalam perencanaannya aspek keseimbangan lingkungan menjadi landasan utama. Sumber mata air di hampir seluruh wilayah kabupaten Tambrauw berasal dari kemampuan vegetasi pohon untuk menyimpan (reservoir) air tanah. Untuk itu, fungsi hidrologis hutan menjadi sangat penting untuk dikelola. Dengan adanya preferensi konsumen akan permintaan produk pertanian maka, promosi kabupaten Tambrauw sebagai lumbung makanan organik (Organic Food Store) sudah sesuai.

\section{KESIMPULAN}

Kondisi yang menghambat pembangunan peternakan di Kabupaten Tambrauw adalah dukungan kebijakan anggaran berbasis kinerja pada penyiapan sumberdaya manusia seperti pelatihan, pos pelayanan terpadu, capacity building instansi teknis terkait, dan studi potensi sumberdaya alam yang tersedia. Diidentifikasinya delapan poin terkait kebutuhan yang meliputi penyediaan pos pelayanan pertanian terpadu, perbaikan bibit tanaman hijauan pakan ternak, pembentukan kelompok peternakan/pertanian terpadu yang permanen, klinik pembibitan ternak, menghubungkan bank dengan kelompok peternak, pengangkatan SDM penyuluh peternakan, tenaga IB dan tenaga paramedis veteriner.

Pengembangan peternakan dengan komoditas ternak yang disesuaikan dengan model/pola yang sesuai dengan kondisi biofisik 
kawasan, pengembangan masyarakat pelaku usahatani peternakan menjadi sentral isu dalam hal pemberdayaan/pembinaan.

\section{DAFTAR PUSTAKA}

Asra, Abuzar, and Slamet Sutomo. 2016. Pengantar Statistika I. 1st ed. Jakarta: PT. Rajagrafindo Persada.

Bamualim, A. dan G. Subowo. 2005. Potensi dan Peluang Pengembangan Ternak Sapi di Lahan Perkebunan Sumatera Selatan. Lokakarya Pengembangan Sistem Integrase Kelapa Sawit-Sapi. Hal. 112-116. Puslitbang Peternakan. Kementerian Pertanian.

BPS, Tambrauw. 2017. Kabupaten Tambrauw dalam Angka Tahun 2017. ISSN / ISBN : 2302-1063.

https://tambrauwkab.bps.go.id/ publication.html.

Elly, F.H., B.M. Sinaga, S.U. Kuntjoro, dan N. Kusnadi. 2008. Pengembangan Usaha Ternak Sapi Rakyat Melalui Integrase Sapi-Tanaman di Sulawesi Utara. Jurnal Litbang Pertanian. 27 (2):63-68.

Fatem, S.M., dan G. Asem. 2015. Kabupaten konservasi sebagai Political Action Pemerintah Daerah dalam Mendukung Konservasi Sumberdaya Alam Hayati: Studi Kasus Kabupaten Tambrauw, Papua Barat. Pros
Sem Nas Mas Biodiv Indonesia. 1 (6): 1403-1410.

Field, A,. J Miles, and Z. Field. 2012. Discovering Statistics Using R. 1st ed. London: Sage Publication Ltd.

Jafri, J., R. Febriamansyah, R. Syahni dan Asmawi. 2015. Interaksi Partisipatif Antara Penyuluh Pertanian dan Kelompok Tani Menuju Kemandirian Petani. Jurnal Agroekonomi. 33 (2): 161-177.

Manly, B.F.J., and J.A.N. Alberto. 2015. Introduction to Ecological Sampling. CRC Press Tailr \& Francis Group.

Mayulu, H., Sunarso, C. I. Sutrisno, dan Sumarsono. 2010. Kebijakan pengembangan peternakan sapi potong di Indonesia. Jurnal Litbang Pertanian. 29 (1): 34-41.

Mirah, R.E., E.K.M. Endoh, J. Pandey, dan A.H.S. Salenduh. 2015. Potensi Pengembangan Ternak Sapi pada Usahatani di Kecamatan Tareran Minahasa. Jurnal Zootek. 35 (1): 46-54.

Moleong, L.J. 1991. Metodologi Penelitian Kualitatif. Penerbit. PT. Remaja RosdakaryaBandung.

Mukson, W. Roessali, dan H. Setiyawan. 2015. Analisis wilayah pengembangan Sapi potong dalam mendukung Swasembada daging di Jawa Tengah. Jurnal Peternakan Indonesia. 16 (1): 26-32. 
Mustofa, A.N., D.A. Wahyuning, dan A. Muhamad. 2015. Analisis Faktor-Faktor yang Mempengaruhi Pengambilan Keputusan Peternakan dalam Memulai Usaha Ternak Sapi Potong di Desa Kedungkumpul Kecamatan Sarirejo Kabupaten Lamongan. Jurnal Ternak. Juni. 6 (1): 1-8.

Priyanto, D., dan I. Irawan. 2008.

Tantangan, Peluang dan Arahan Pengembangan Peternakan di Provinsi Papua. Seminar Nasional Teknologi Peternakan dan Veteriner. Procedings. Hal 862-874.

Rahmanto, B. 2014. Analisis Usaha Peternakan Sapi Rakyat. Pusat Penelitian dan Pengembangan Sosial Ekonomi Pertanian. ICASERD working paper. No. 59.

Santoso, S. 2012. Aplikasi SPSS Pada Statistik Non Parametrik. 1st ed. Gramedia. Jakarta.

Talib, C., I. Innounu, dan A. Bamualim. 2007. Restrukturisasi Peternakan Di Indonesia. Analisis Kebijakan Pertanian. 5 (1): 1-14.

Winarso, B., R. Sajuti, dan C. Muslim. 2005. Tinjauan Ekonomi Ternak Sapi Potong di Jawa Timur. Forum Penelitian Agroekonomi. 23 (1): 61-71.

Yin, R.K. 2000. Studi Kasus; Desain dan Metode. Penerbit PT. Radja Grafindo Persada. Jakarta.
Yoyo, M. Sugiarto, dan A. Priyono. 2013. Analisis Potensi Peternak dalam Pengembangan Ekonomi Usaha Kambing Lokal di Banyumas. Jurnal Ilmiah Peternakan. UNSOED. 1 (2): 619-626. 